\title{
Characterization of the Palmyra Petiole as a Biovegetal Material of Artisanal Construction in Chad
}

\author{
Ngargueudedjim Kimtangar ${ }^{1, *}$, Djidengar Lazare ${ }^{1,2}$, Deudjonbe Baruc ${ }^{1,2}$, Beda Tibi ${ }^{2}$, \\ Nzie Wolfgang ${ }^{2}$ \\ ${ }^{1}$ Laboratory of Study and Research in Industrial Techniques (LERTI), University of N'Djamena, N'Djamena, Chad \\ ${ }^{2}$ Faculty of Sciences, University of Ngaoundéré, Ngaoundéré, Cameroon
}

Email address:

kimta_ernest@yahoo.fr (N. Kimtangar)

${ }^{*}$ Corresponding author

To cite this article:

Ngargueudedjim Kimtangar, Djidengar Lazare, Deudjonbe Baruc, Beda Tibi, Nzie Wolfgang. Characterization of the Palmyra Petiole as a Biovegetal Material of Artisanal Construction in Chad. International Journal of Materials Science and Applications.

Vol. 8, No. 5, 2019, pp. 90-97. doi: 10.11648/j.ijmsa.20190805.13

Received: August 14, 2019; Accepted: October 9, 2019; Published: October 23, 2019

\begin{abstract}
The palmyra is a wood particularly famous for its resistance to xylophages and various bad weather. But the determining factors of this resistance are unknown. This base material is available in the form of lignocellulosic waste generated in large quantities, following its grooming, maintenance and felling. This lignocellulosic waste is not valued in Chad. Its petiole is the biovegetal material widely used in Chad for the artisanal manufacture of furniture and other works. The present study concerns the determination of its physical, chemical and mechanical characteristics. We used chemical analyzes, physical tests and mechanical tests in three-point flexion, intension and in compression. Its contents in cellulose, lignin and Hemicellulose obtained justify its resistance to physical and chemical degradation and its attack by termites. The values of its mechanical characteristics obtained place it between the category D50 and D60 of hardwoods. Those of its physical properties place it among the light woods. This study, the first on the knowledge of the scientific and technical properties of the palmyra of Chad, opens perspectives on a new field of study on the behaviour of this abundant natural raw material with a view to its valorisation and its rational use in various fields, such as pulp and building construction and public works.
\end{abstract}

Keywords: Petiole, Palmyra, Wood, Physical Characteristics, Chemical Characteristics, Mechanical Characteristics

\section{Introduction}

The problematic of our study is the lack of scientific data on the petiole of Chadian Palmyra (Figure 1). This part of the palmyra is a natural material widely used as fence posts for fields and concessions. It is also used for making beds, chairs (Figure 2) and other furniture and house hold structures. Its current use is done empirically. That is why this study is conducted to determine its scientific characteristics in order to consider its rational use and its valuation.

The scientific characteristics determined in this work are:

Chemical properties: contents of cellulose, lignin, hemicellulose;

Physical characteristics: density, moisture content, dry matter content, ash content, linear shrinkage, volume shrinkage and radial shrinkage;
Mechanical characteristics: the longitudinal modulus of elasticity and the maximum tensile stress in bending, compression and tension in the direction of the fibers.

All analyzes and tests are carried out in the different laboratories of the Faculty of Exact and Applied Sciences of the University of N'Djamena.

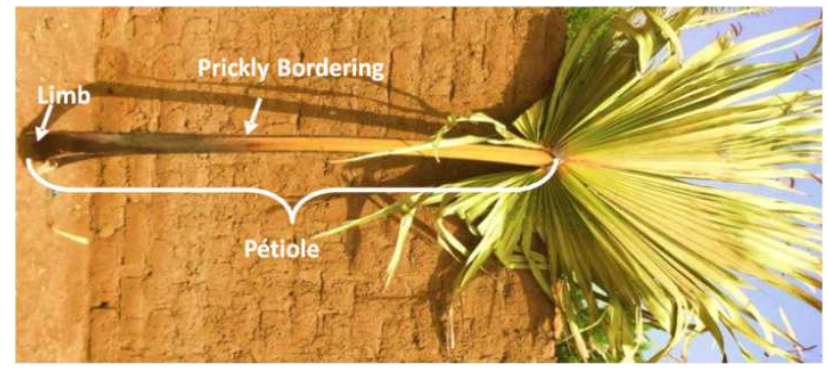

Figure 1. Petiole of the palmyra and its different parts. 


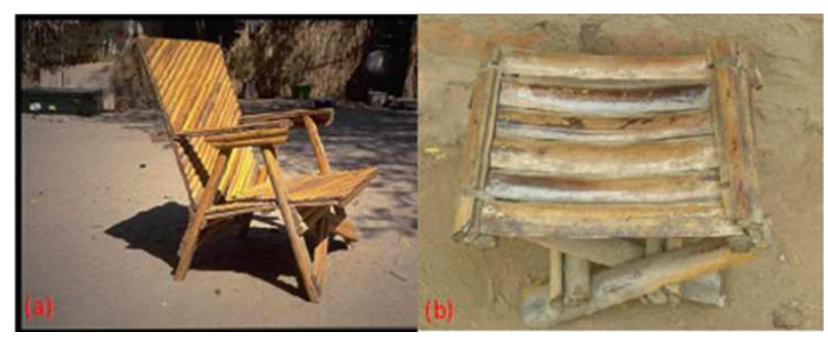

Figure 2. Furniture made with the petiole of the palmyra.(a): rifle, (b): armchair.

\section{Method}

\subsection{Material of the Study}

The material of study of our work is the petiole of the palmyra aged about 30 years. Of length 150 to $220 \mathrm{~cm}$ (Figure 1) in an adult palmyra, the petiole is split at its base about $20 \mathrm{~cm}$, forming the limb. It is by his limb that he attaches himself to the trunk of his tree. Relatively flattened on its upper face and convex on its lower face, it is lined with prickles irregularly distributed on its bordering. Samples are taken from Koundoul, a town at $25 \mathrm{~km}$ in south of N'Djamena.

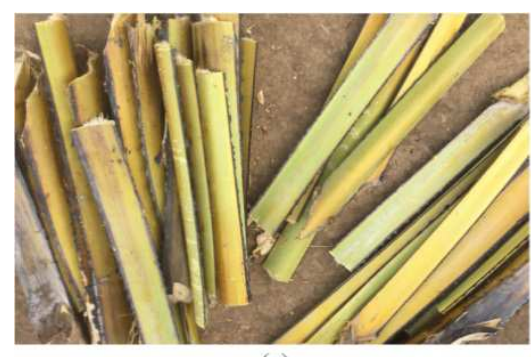

(a)

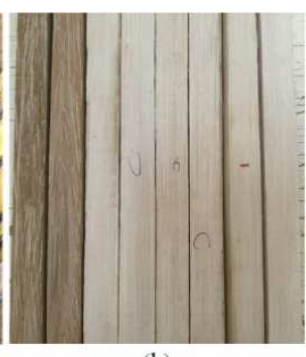

(b)
Figure 3. Samples of petiole, (a): non machined, (b): machined after drying.

\subsection{Methodology}

To obtain representative samples of the whole, we cut twenty-five (25) petiole specimens (Figure 3a) on different similar aged palmyra. These samples were dried in the sun for one month. Samples for mechanical tests (Figure 3b) were machined.

\subsubsection{Determination of the Chemical Properties of the Petiole of Palmyra}

This part of the study concerns the determination of the contents of cellulose (C), Hemicellulose (HC), lignin (L) and extractable matters (minerals, starch, proteins).

The petiole samples of the palmyra were crushed and powdered. The powder obtained is subsequently sieved before the chemical tests.

The chemical analysis began with the extraction of extractable matters. For this, we treated $8 \mathrm{~g}$ of the dried petiole powder in $400 \mathrm{ml}$ of ethanol-toluene mixture in an Erlenmeyer flask under roughness and reflux at $80^{\circ} \mathrm{C}$ for 8 hours.

The percentage $\mathrm{W}_{3}(\%)$ of the fats and waxes is calculated using formula (1).

$$
\mathrm{W}_{3}(\%)=100\left(\mathrm{~W}_{1}-\mathrm{W}_{2}\right) / \mathrm{W}_{1}
$$

$\mathrm{W}_{1}$ and $\mathrm{W}_{2}$ are the masses of the fibers before and after the treatment.

For the determination of the percentage of lignin, one gram (1g) of the residue from the treatment in the ethanol-toluene mixture is treated with $75 \%$ sulphuric acid solution for 2 hours. After the addition of $500 \mathrm{ml}$ of water, the solution is heated to boiling and refluxing for 4 hours. The residue is then filtered and washed with $500 \mathrm{ml}$ of water and dried in the oven at $100^{\circ} \mathrm{C}$ and weighed. Since the lignin is in soluble in $75 \%$ sulphuric acid, this residue contains essentially lignin. Its percentage is calculated using formula (2).

$$
\mathrm{L}(\%)=\mathrm{K}_{2} /\left(\mathrm{K}_{1}\left(100-\mathrm{W}_{3}\right)\right)
$$

$\mathrm{K}_{1}$ and $\mathrm{K}_{2}$ are respectively the masses of the fibers before and after the treatment with $75 \%$ sulphuric acid.

Four grams (4g) of the fat and wax-free residue are treated in the mixture of glacial acetic acid and sodium hypochloride in a water bath maintained at a temperature between $70^{\circ} \mathrm{C}$ and $80^{\circ} \mathrm{C}$ for 5 hours with stirring. The residue obtained after washing and drying contains hollocellulose (HOC) which is composed of cellulose and hemicellulose. Its percentage is calculated using formula (3).

$$
\operatorname{HCO}(\%)=\mathrm{N}_{2} /\left(\mathrm{N}_{1}\left(100-\mathrm{W}_{3}\right)\right)
$$

$\mathrm{N}_{1}$ and $\mathrm{N}_{2}$ are respectively the masses of the fibers before and after the treatment in the mixture of glacial acetic acid and sodium hypochloride.

For the determination of cellulose, three grams $(3 \mathrm{~g})$ of dried hollocellulose are treated successively in $17.5 \%$ sodium hydroxide solution, $8.3 \%$ sodium hydroxide solution and 10\% acetic acid solution. The mass of the residue obtained after filtering and washing hollocellulose treated with water allows to be calculated the percentage of cellulose $(\mathrm{C} \%)$, using formula (4).

$$
C(\%)=\frac{M_{2}}{M_{1}} W_{3}
$$

$\mathrm{M}_{1}$ and $\mathrm{M}_{2}$ are respectively the masses of the fibers before and after this last treatment.

The rate of Hemicellulose is deduced from the rate of hollocellulose and cellulose using formula (5):

$$
\mathrm{HC}(\%)=\mathrm{HCO}(\%)-\mathrm{C}(\%)
$$

\subsubsection{Determination of the Physical Characteristics of the Petiole}

The dehydration method is used to determine the moisture content. After weighing with the electronic balance, the crucible containing the sample is kept in the oven for 3 hours at a constant temperature of $103^{\circ} \mathrm{C}$. It is cooled and weighed every four hours a part until obtaining a mass variation between two successive weighings less than or equal to $0.5 \%$. Subsequently, the anhydrous test piece is weighed at $0.5 \%$ of its mass after cooling in the desiccator. This weighing must be carried out rapidly in order to avoid 
moisture up take of more than $1 \%$.

The moisture content of the test piece is calculated using formula (6).

$$
\mathrm{H}(\%)=100\left(\mathrm{~m}_{\mathrm{h}}-\mathrm{m}_{0}\right) / \mathrm{m}_{0}
$$

$\mathrm{m}_{\mathrm{h}}$ and $\mathrm{m}_{0}$ are respectively the gram masses of the crucible containing the test piece before dehydration and the anhydrous specimen.

The density $\left(\mathrm{Kg} / \mathrm{m}^{3}\right)$ of wood is a basic physical property for its qualification. It has an influence on the mechanical strength of wood.

The dimensions and the mass of the sample measured in the desiccator are used to calculate its density.

For determining the ash content, we used the principle of the removal of organic matter in the petiole sample by calcination at a defined temperature in a given time. The ash rate $\mathrm{TC}(\%)$ is calculated using formula (7).

$$
\operatorname{TC}(\%)=100\left(\mathrm{~m}_{1}-\mathrm{m}_{0}\right) / \mathrm{m}
$$

$\mathrm{m}_{0}$ : mass (in gram) of the empty crucible;

$\mathrm{m}_{1}$ : mass (in gram) of the crucible and the residue after calcination;

$\mathrm{m}$ : Mass (in gram) of the crucible and the sample before calcination.

Retractability is the variation of petiole sample size as a result of varying moisture in the sample

The volume shrinkage (retractability) $\mathrm{B}(\%)$ is calculated using formula (8).

$$
\mathrm{B}(\%)=100\left(\mathrm{~V}_{\mathrm{h}}-\mathrm{V}_{\mathrm{s}}\right) / \mathrm{V}_{\mathrm{s}}
$$

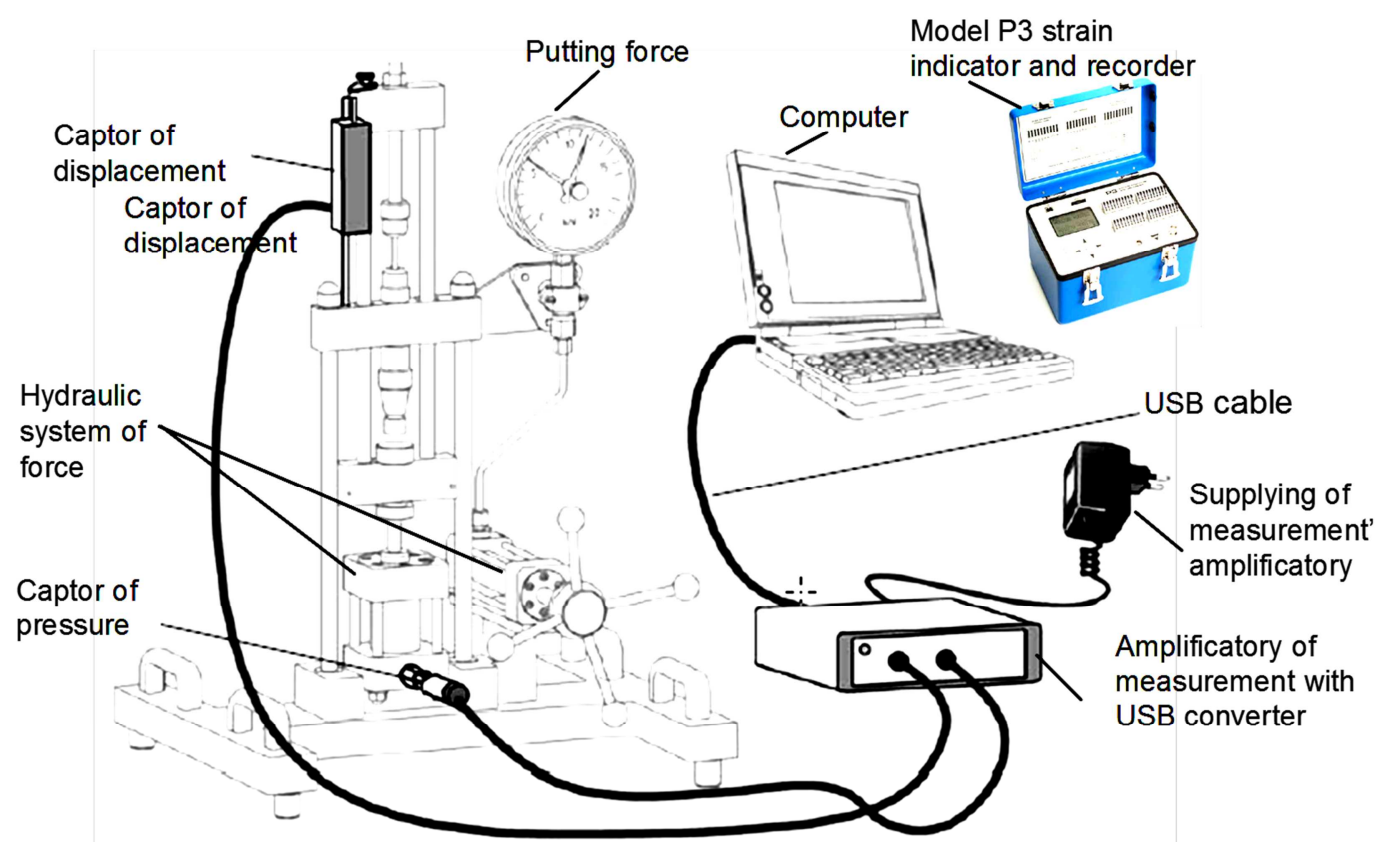

Figure 4. Device of the mechanical tests.

This machine is equipped with a data acquisition system connected to a computer and a Model P3 extensométrie bridge.
$\mathrm{V}_{\mathrm{h}}, \mathrm{V}_{\mathrm{s}}$ are respectively the volumes of the test piece in the wet state and in the anhydrous state.

The longitudinal retractability $\mathrm{L}(\%)$ is calculated using formula (9).

$$
\mathrm{L}(\%)=100\left(\mathrm{~L}_{\mathrm{h}}-\mathrm{L}_{\mathrm{s}}\right) / \mathrm{L}_{\mathrm{s}}
$$

$\mathrm{L}_{\mathrm{h}}, \mathrm{L}_{\mathrm{s}}$ are respectively the lengths of the wet and anhydrous test pieces, measured in the longitudinal direction of the fibers.

The transverse shrinkage $\mathrm{T}(\%)$ is calculated using formula (10).

$$
\mathrm{T}(\%)=100\left(\mathrm{~T}_{\mathrm{h}}-\mathrm{T}_{\mathrm{S}}\right) / \mathrm{T}_{\mathrm{S}}
$$

$\mathrm{T}_{\mathrm{h}}, \mathrm{T}_{\mathrm{s}}$ are the transverse lengths of the wet and anhydrous specimen, measured in the direction perpendicular to the direction of the fibers.

\subsubsection{Mechanical Tests}

This part of the study concerns the determination of the longitudinal elastic modulus (Young's modulus) and rupture strength of the petiole subjected to three-point bending (perpendicularly to the direction of fibers), axial compression and axial tensile tests (in the longitudinal direction of fibers).

These three types of mechanical tests are carried out on a universal machine Model WP300-20 (Figure 4) whose characteristics are:

Maximum strength: $20 \mathrm{kN}$;

Maximum pressure of the hydraulic system: 100 bars; Maximum displacement: $50 \mathrm{~mm}$ with accuracy of $0.01 \mathrm{~mm}$. 
specimens until breaking.

The forces and displacements are automatically recorded in the computer aid of an acquisition system and a data processing driver. The displacement-force curves were plotted and displays in real time on the screen.

We assumed that the petiole beams are rectilinear, of negligible weight in front of the applied load, macroscopically homogeneous, perfect (without defects such as knots, wounds).

The rupture stress of the petiole sample is given by:

$$
\sigma_{\mathrm{r}}=\frac{3 \mathrm{PL}}{2 \mathrm{bh}^{3}}
$$

Where $\mathrm{P}$ is the maximum load applied.

$\mathrm{L}$ is the distance between the two supports.

$\mathrm{b}$ and $\mathrm{h}$ are respectively the width and the thickness of the specimen.

The maximum displacement of the specimen is given by formula (12).

$$
f_{\max }=\frac{\mathrm{PL}^{3}}{4 \mathrm{Ebh}^{3}}
$$

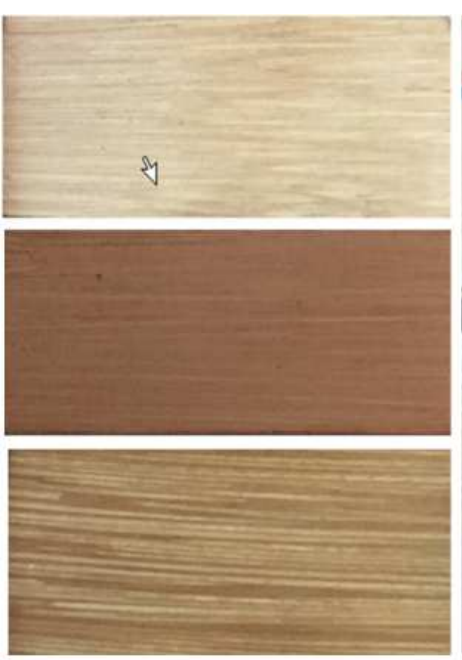

(a)
The Young's modulus is calculated using formula (13):

$$
E=\frac{P L^{3}}{4 b h^{3} f_{\max }}
$$

In order to take into account the recommendations of the European Lumber Standards [1], the Young's modulus value is calculated at a moisture content of $12 \%$ using relation (14).

$$
\mathrm{E}_{12}=\mathrm{E}_{\mathrm{H}}(1-0.015 \times(\mathrm{H}-12))
$$

(ii) Compression tests

The tests carried out consist in applying a compressive force to a test piece which will cause its crushing.

Two types of test pieces are tested:

Six (6) specimens without strain gauge (Figure 5a) are used for the determination of the breaking stress and the Young's modulus.

Two other specimens equipped with strain gauges (Figure $5 b$ ) are used for the determination of the Young's modulus.

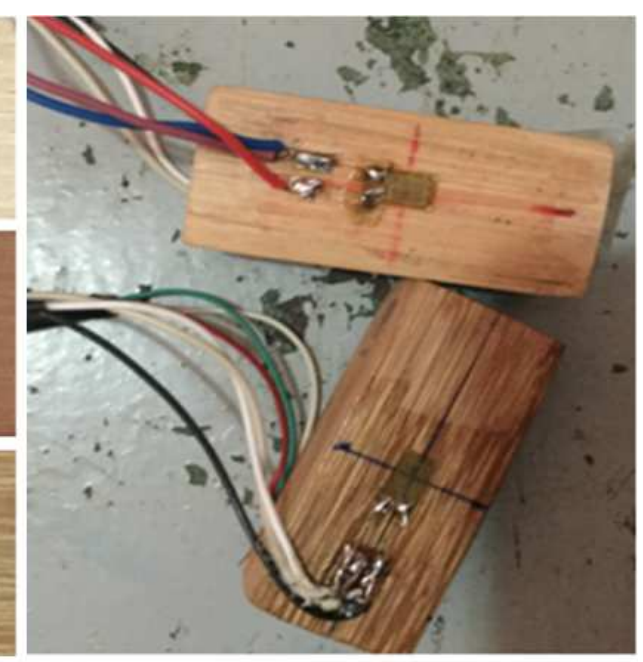

(b)

Figure 5. Test specimens for compression testing; (a): test pieces without strain gauge; (b): specimens equipped with strain gauges.

The stresses and deformations are automatically recorded on the computer in the case of the determination of the breaking stress of the specimens without strain gauges. They are simultaneously recorded in an extensométrie bridge Model P3 and in the computer in the case of specimens equipped with strain gauges.

The maximum compressive stress $\sigma_{\mathrm{r}}(\mathrm{MPa})$ is calculated using the relation (15).

$$
\sigma=\mathrm{F} / \mathrm{A}
$$

Where $\mathrm{F}$ is the maximum compression force in Newton (N), A is the area of the initial section of the sample in $\mathrm{mm}^{2}$.

(iii) Traction tests

The test pieces used are flat (Figure 6).

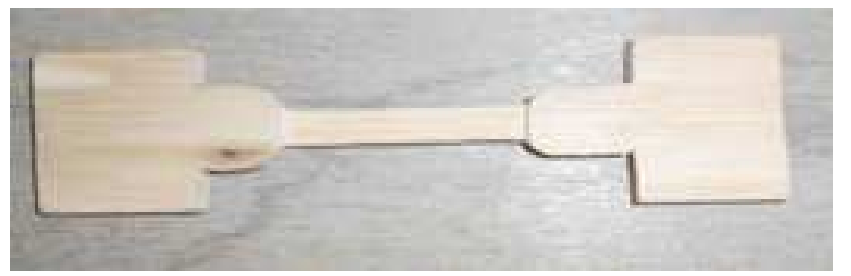

Figure 6. Geometry of the tensile test piece.

The tensile test is the most well-known mechanical characterization of material.

It consists in causing the extension of a specimen by applying a load at its two ends engaged in the jaws of the traction machine. 
The tensile strength $\sigma_{\mathrm{r}}(\mathrm{MPa})$ is calculated using formula (16).

$$
\sigma_{\mathrm{r}}=\mathrm{F}_{\max } / \mathrm{A}_{0}
$$

Where $F_{\max }$ is the maximum compression force in Newton $(\mathrm{N}), \mathrm{A}$ is the area of the initial section of the sample in $\mathrm{mm}^{2}$.

Data from specimens that are broken out side of the area of the effective length are not considered in the treatment of the results.

\section{Results}

Table 1 gives the chemical composition of the palmyra petiole obtained.

Table 1. Chemical composition of the palmyra petiole obtained.

\begin{tabular}{llll}
\hline Cellulose (\%) & Lignin (\%) & Hemicellulose (\%) & Extractives (\%) \\
\hline 54,51 & 23 & 14,49 & 8,00 \\
\hline
\end{tabular}

Table2 shows the physical characteristics of the petiole obtained.

Table 2. Values of the physical characteristics of the petiole.

\begin{tabular}{lllllll}
\hline Density MV (kg/m $\mathbf{3})$ & $\begin{array}{l}\text { Moisture } \\
\text { content H (\%) }\end{array}$ & Dry matter (\%) & $\begin{array}{l}\text { Ash content TC } \\
\mathbf{( \% )}\end{array}$ & $\begin{array}{l}\text { Volume shrinkage } \\
\text { B (\%) }\end{array}$ & $\begin{array}{l}\text { Linear shrinkage } \\
\text { RL (\%) }\end{array}$ & $\begin{array}{l}\text { Transverse } \\
\text { shrinkage RT (\%) }\end{array}$ \\
\hline $526.73 \pm 36.06$ & 19.27 & 80.27 & $0.53 \pm 0.1$ & $10.01 \pm 0.8$ & $0.18 \pm 0.2$ & $3.51 \pm 0.9$ \\
\hline
\end{tabular}

Figure 7 shows the curve of the evolution of the displacement as a function of the force.

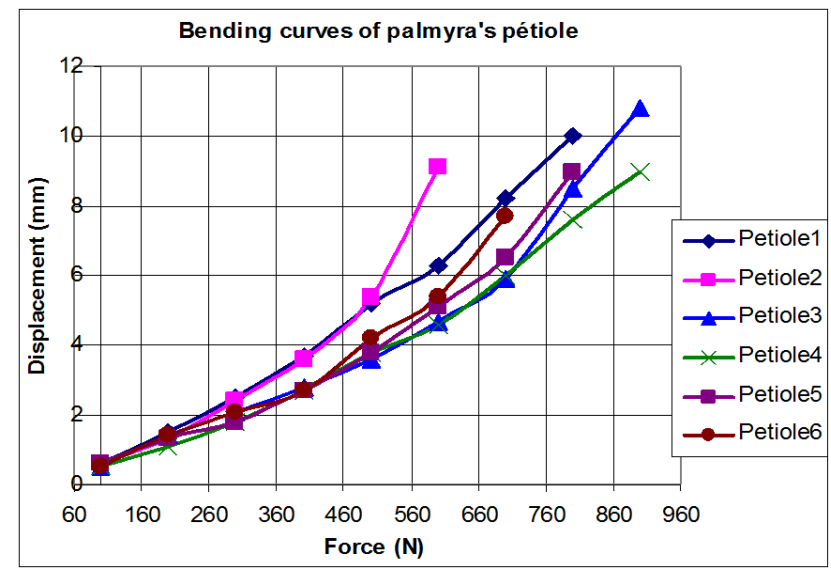

Figure 7. Displacement-Force curves of the specimens subjected to the bending.

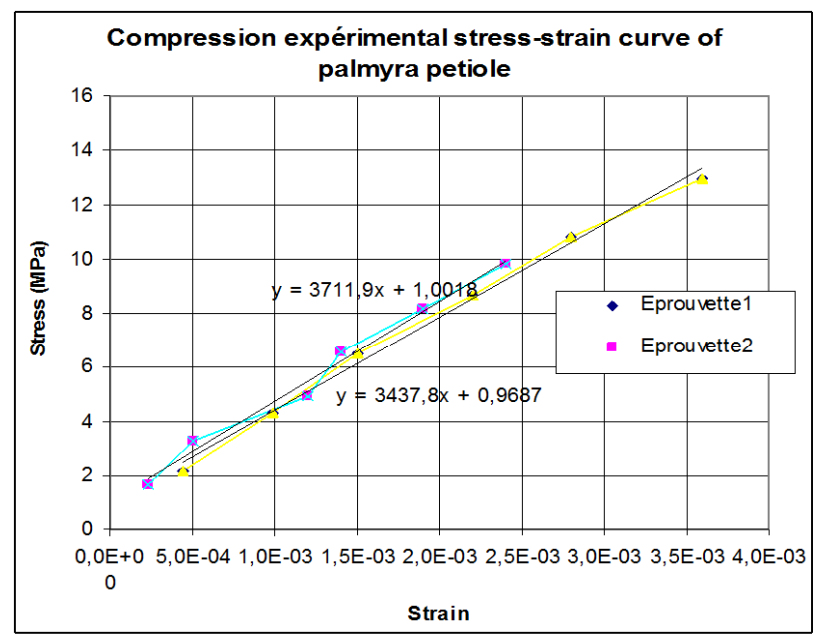

(a)
Figures 8 and 9 give the stress-strain curves of the specimens of the petiole of palmyra solicited in axial compression.

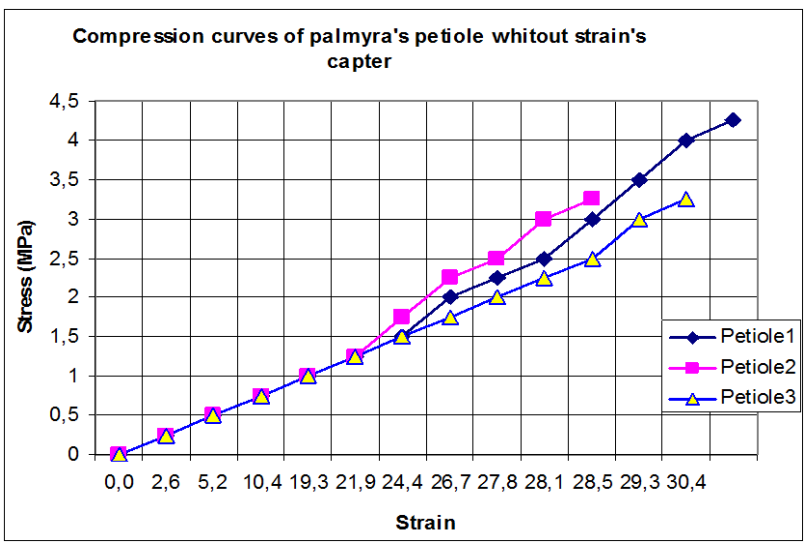

Figure 8. Compression Stress-Strain curves obtained with specimens without strain gauges.

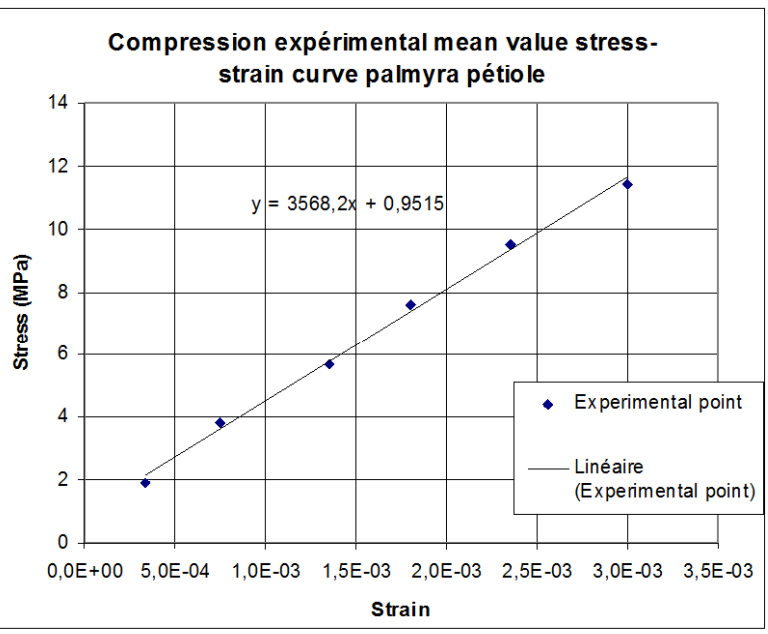

(b)

Figure 9. CompressionStress-Strain curves obtained with test pieces equipped with strain gauges; (a): Curve for each specimen, (b): curve with mean values from the two specimens. 
Figure 10 shows the tensile stress-strain curves of palmyra petiole for each of the six specimens (a) and the tensile stressstrain curve of the average values for the six specimens (b).

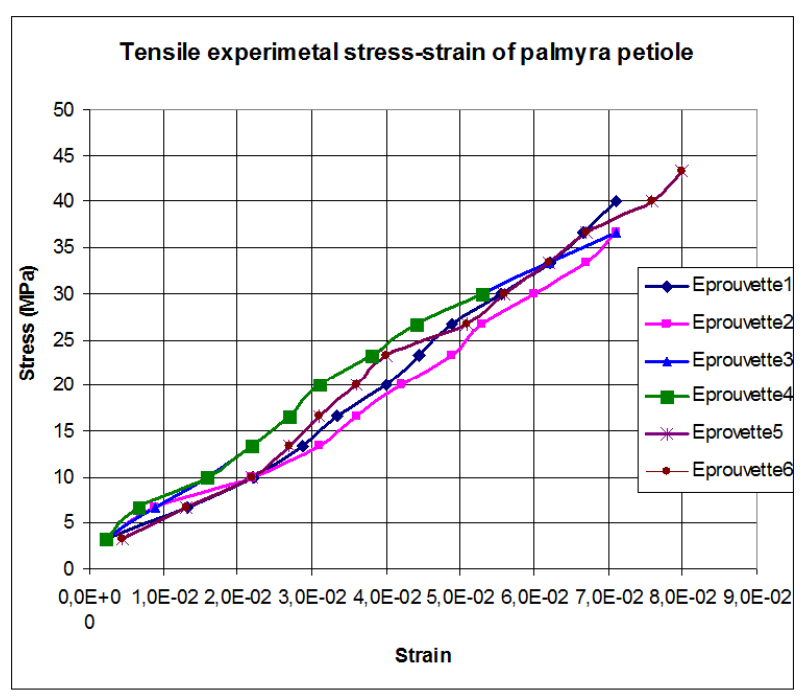

(a)

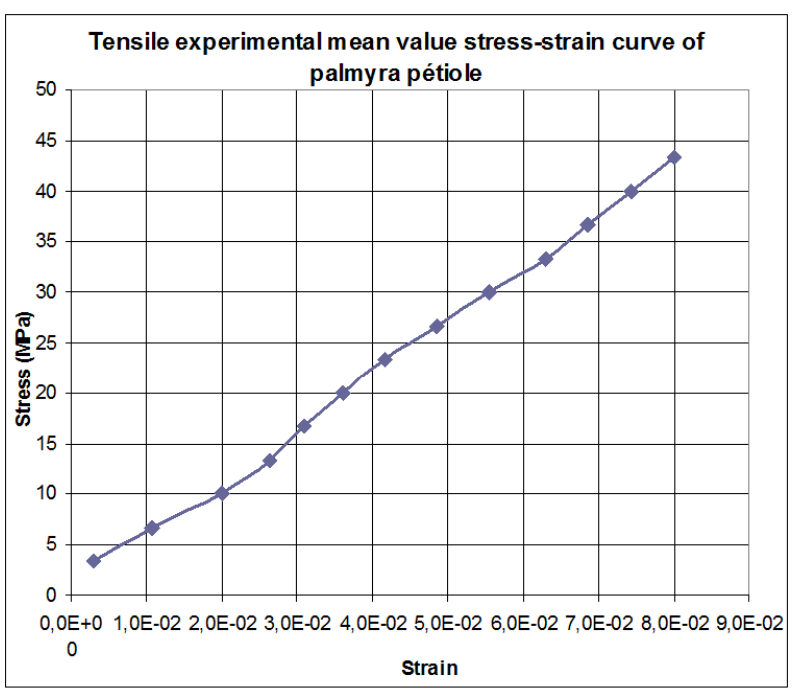

(b)

Figure 10. Tensilestress-strain curves of the petiole of palmyra; (a): curve for each specimen; (b): curve of plotted with average values of stress and average values of strain of the six specimens.

\section{Discussion}

The table 1 shows that the cellulose content $(54.51 \%)$ is considerably high relative to the content of lignin (23\%) and Hemicellulose $(14.49 \%)$. This high rate of cellulose will allows petiole to roam to be resistant to physical and chemical degradation. Cellulose is the essential element of wood burning. Lignin, called the "glue" of wood, encrusts and strengthens cell membranes. It is like cement between the fibers of the wood and as a stiffening element inside the fibers and allows some trees to reach a height of more than $100 \mathrm{~m}$ [1]. Lignin protects the plant against the attack of biological agents (bacteria, fungus, termites) [2]. It is found that the petioles of palmyra are less attacked by the insects. Hemicelluloses are smaller, branched molecules. They provide the link between lignin and cellulose in each layer of the cell wall. Hemicelluloses do not have a significant mechanical role; but their low content can cause greater accessibility to cellulose, an increase water absorption and a decrease of dry mass $[3,4]$. Note that the contents of its chemical components are lower than those of the palmyra (Table 3).

Taking into account the results of the work of Mbaye Dieng and al. [5], we can say that the extractable materials contain polyphenols and antioxidants. Komlan Lolo and Sonnou Tiem [6] find that the determining factors of the resistance of the palmyra to the xylophages and the various bad weathers are still unknown. From some wood extracts, Dünisch O. and al. [7], Grace J. K. and al. [8], Toscioglu C. and al. [9] have been able to isolate wood preservatives against termites. The results of their studies enlarge the way for understanding the natural resistant of any woods.

Table 3. Chemical composition of the palmyra $[10,11]$.

\begin{tabular}{llllll}
\hline Origin of the palmyra & Part of the wood & Cellulose (\%) & Lignin (\%) & Hemicellulose (\%) & Extractables (\%) \\
\hline \multirow{2}{*}{ Houndouma [5] } & Duramen & 63.21 & 19.36 & 09.60 & \\
Malfana [6] & Sapwood & 61.89 & 19.68 & 11.32 & 1.33 \\
\hline
\end{tabular}

About the Physical Characterization, table 2 shows that the petiole of palmyra consists essentially of the dry matter $(80.27 \%)$. Its moisture content is $19.27 \%$. The water content gives an idea on the dimensional change (shrinkage or swelling), on the density and on the mechanical properties of the wood. This low value of moisture content is one of the factors in favour of the non-rot of the petiole of palmyra in the presence of natural environmental conditions. The ash content in the petiole of the palmyra is $0.53 \pm 0.1 \%$. This low value of the ash rate justifies the choice of the petiole of palmyra by the peasant households of Chad as the best cooking fuel. The average value of the density of the petiole of the palmyra determined at a moisture content of $19.27 \%$ is $526.73 \mathrm{~kg} / \mathrm{m}^{3}$. According to wood standards (NFB51004, NFB51008), its density at a moisture content of $12 \%$ is 320 $\mathrm{kg} / \mathrm{m}^{3}$. The density of palmyra petiole is similar to those of bamboo, fir or spruce whose densities are between 300 and $400 \mathrm{~kg} / \mathrm{m}^{3}$ [1]. Density has no significant effect on the mechanical state of wood of these species. The density varies very slightly in softwoods, especially for maritime pine and Aleppo pine [12]. These values are lower than those of the palmyra which are given in the table 4 . Farid Touloum and B. 
Agoudjil $[13,14]$ found for the date palm petiole (DegletNour), a variety of palm, a density between 187 and 389 $\mathrm{kg} \cdot \mathrm{m}^{-3}$. They attribute this low value of the density to the high porosity of this wood.

Table 4. Physical properties of palmyra at 12\% of moisture content [15].

\begin{tabular}{|c|c|c|c|c|c|c|c|}
\hline $\begin{array}{l}\text { Part of the } \\
\text { palmyra }\end{array}$ & $\begin{array}{l}\text { Density } \\
\operatorname{MV}\left(\mathrm{kg} / \mathrm{m}^{3}\right)\end{array}$ & $\begin{array}{l}\text { Moisture } \\
\text { content H (\%) }\end{array}$ & $\begin{array}{l}\text { Dry matter } \\
(\%)\end{array}$ & $\begin{array}{l}\text { Ash content TC } \\
(\%)\end{array}$ & $\begin{array}{l}\text { Volume } \\
\text { shrinkage B (\%) }\end{array}$ & $\begin{array}{l}\text { Linear shrinkage } \\
\text { RL (\%) }\end{array}$ & $\begin{array}{l}\text { Transverse } \\
\text { shrinkage RT (\%) }\end{array}$ \\
\hline Duramen & 894.40 & $15.86 \% \pm 1.18$ & & $1.4 \% \pm 0.004$ & $6.05 \% \pm 0.01$ & $2.62 \% \pm 0.31$ & $0.57 \% \pm 0.26$ \\
\hline Sapwood & & $44.56 \% \pm 2.95$ & & $1.00 \% \pm 0.004 \%$ & & & \\
\hline
\end{tabular}

This density value places the palmyra petiole in the category of very light woods. The values of its volumetric, longitudinal and tangential shrinkage rates place it in the mean shrinkage category $[1,16]$.

About the mechanical characteristics, note that the average values of fracture stress and Young's modulus in bending of the palmyra petiole obtained by the least square method are respectively $\sigma_{\mathrm{r}}=65.40 \pm 13.95 \mathrm{MPa}$ and $\mathrm{E}=11410.47 \pm 579.08$ $\mathrm{MPa}$ at a moisture content of $19.27 \%$. At a moisture content of $12 \%$, the average Young's modulus is $10166.16 \mathrm{MPa}$. These values are lower than those of the palmyra which are $\sigma_{\mathrm{r}}=180.01 \mathrm{MPa}$ and $\mathrm{E}=15044.87 \mathrm{MPa}[17,18]$. In longitudinal compression, the mean value of the Young's modulus of the palmyra petiole obtained with the specimens without strain gauge is $1415.74 \mathrm{MPa}$. The average value of its breaking stress obtained with these test pieces is $29.81 \pm 3.17 \mathrm{MPa}$. That obtained with specimens equipped with strain gauges is $3568.2 \pm 651.07 \mathrm{MPa}$. We noted a difference of 2152.46 MPa between the values of the Young's modulus obtained with the two methods. This difference highlights the errors that are made in the compression tests by measuring the overall deformation of the specimen. Indeed, the over all deformation Consists largely of the crushing of the two heads of the specimen. The use of the gauges allows a measuring only the deformation of the specimen by eliminating the crushing of the heads. The value of tensile breaking stress in the direction of the fibers obtained is $\sigma_{\mathrm{r}}=37.77 \pm 5.69 \mathrm{MPa}$. The value of longitudinal elastic modulus in the same direction is $E=1138.96 \pm 66.16$ $\mathrm{MPa}$. The results of the mechanical tests show that the petiole of palmyra has mechanical characteristics in bending superior to those of traction and compression. These results allow us to affirm that the general hypotheses giving a modulus of elasticity equivalent in compression, traction and thus in flexion is not valid for the anisotropic materials. In fact, the flexural strength of wood often exceeds the compressive strength if the wood is of very good quality.

\section{Conclusion}

We can say that the main objective of our study, which is the chemical, physical and mechanical characterization of the petiole of palmyra, is achieved.

The values of the mechanical characteristics of the petiole of palmyra determined allow us to classify between the D50 and D60 category of hard wood. Those of the physical characteristics place it among the light woods and the best organic. And its chemical characteristics obtained it among the woods resistant to attack pathogens and decay. Its high dry matter content is an asset for its use as a pulp material. Its fibrous character confirms its belonging to noble materials.

Since the petiole of the palmyra is an abundant and easily reproducing natural resource in $\mathrm{Chad}$, it is conceivable to undertake a techno-economic study with a view to its valorisation as a natural raw material for the manufacture of furniture and decorative objects in modern habitats.

A commercialization study of the palmyra products sector involving the three research actors (peasants, developers, and researchers) at the different stages of the research is essential to develop (enhance) this wood whose current management of the abundant waste constitutes an economic shortfall.

\section{References}

[1] J. Gerard and al. 1998 "Synthesis on the technological characteristics of reference of the main African commercial woods", FORAFRI Series 1998, 189 pages, document 11. International Campus of Bailla Guet, Montpelier France.

[2] Do Thi Vivi "Composite natural fiber materials/biodegradable or non-biodegradable polymers". $\mathrm{PhD}$ thesis, University of GRENOBLE, July 20, 2011.

[3] Letelier Maxime and Fleurent Didier Valérie. Chemical, physical and mechanical characterization of old piles. Graduation projectEngineer $3^{\text {rd }}$ year of 2011-2012, 70p. University of Lorraine. http://www.cfcopies.com/V2/leg/leg_droi.php, $\mathrm{http}: / / \mathrm{www} . c u l t u r e . g o u v . f r /$ culture/infospratiques/droits/protection.htm.

[4] UÇAR G., YILGÖR N. Chemical and environmental properties of 300 years waterlogged wood (Abiesbornmülleriana M.). Holzals Roh-und Werkstoff. 1995, Vol. 53, No. 2, p. 129-132.

[5] Mbaye Dieng, Alioune Dior FALL, Kady Diatta, William Diatta and Emmanuel Bassene; Determination of polyphenols and antioxidant activity of male leaves and inflorescences of Borassus aethiopum, Mart. (Arecaceae); http://ajol.info/index.php/ijbcs, International Journal of Biological and Chemical Sciences. 9 (1): 1067-1071, April 2015, ISSN: 1997-342X (Online), ISSN: 1991-8631 (Print), $\mathrm{http} / / /$ indexmedicus.afro.who.int

[6] Komlan Lolo, Sonnou Tiem, Singularity of Borassus Aethiopum Wood by its Physiology. European Scientific Journal, November 2017 edition Vol. 13, No. 33, ISSN: 18577881 (Print) e-ISSN: 1857-7431, Doi: 10.19044/esj.2017. v13, n33, p463, http://dx.doi.org/10.19044/esj.2017.v13n33p463

[7] Dünisch O., Latorraca, JV de F. (2015). The assimilate partitioning importance for heartwood extractives formation in Robinia Pseudoacacia 1. Of different ages. Florestae Ambiente, 22 (3): 400-407. 
[8] Grace JK, D. McG. Ewart, DMc G, Tome CHM., 1996. Termite resistance of wood species grown in Hawaii. Forest Prod. J., 46 (10): 57-60.

[9] Tascioglu C, Troya T de, Sivrikaya. (2012). Termiticidal properties of some wood and bark extracts used as wood preservatives. BioResources, 7 (3): 2960-2969.

[10] N. Kimtangar, E. Mbaingone, N. Nadjitonon and R. Agnes, Jan. 2016. "Anatomical and chemical characterization of the palmyra (Borassus aethiopum Mart.) of Chad/Central Africa". International Journal of Innovation and Scientific Research, IJISR-ISSR, Vol. 20 No. 1, pages 129-137.1Jan.2016. ISSN: 2351-8014, http://www.ijisr.issr-journals.org/.

[11] Bianpambé Hinperé Wedjou, 2014. "Physicochemical and mechanical characterization of the palmyra wood (Borassus aethiopum Mart.) of Chad". Master thesis, Ngaoundéré University.

[12] M. Meite, A. Laanaa, A. Famiri, A. Yeznasni, M. Chergui, El Ghorba and M. Ziani, 2007. Study of the influence of physical properties on the mechanical behaviour of woods. Maritime pine and pine for application to wind energy. Renewable Energies Review CER'07 Oujda 61-65.

[13] Farid Touloum, 2018, Contribution to the development of insulating materials in the building sector. Use of date palm wood (Phoenix Dactylifera L). Thesis submitted from the University Mohamed Khider-Biskra with a view to obtaining a $\mathrm{PhD}$ degree in Mechanical Engineering, 161p.
[14] Farid Touloum, Adel Benchabane, Abdelhak Kaci; Valorisation of natural reinforcing fibers for composite materials. JM'EMP08 EMP, Bordj El Bahri, 10-11 Avril, 2012. https://www.researchgate.net/publication/289532078.

[15] K. Ngargueudedjim, N. Ngarmaim, B. Bassa, N. Allarabaye, M. Fogué, November 2015. "Physical characterization of the palmyra wood (Borassus aethiopum Mart.) of Chad/Central Africa". International Journal of Innovation and Applied Studies, ISSN: 2028-9324, Vol. 13, No. 3, pp 553-560. http://www.ijias.issr-journals.org/.

[16] Y. Carignan, J. Frappier, S. Gagnon, S. Gilbert, 2015. "Technical guide on the design of beams and columns in large wood", cecobois.

[17] Ngargueudedjim K. and al., Mechanical Characteristics of Tall-Palm (Borassus aethiopum Mart., Arecaceae) of Chad/Central Africa. International Journal of Engineering and Technical Research (IJERT). ISSN: 2321-0869 (O) 2454-4698 (P), Volume-3, Issue-9, pp. 125-128, September 2015. www.erpublication.org.

[18] Ngargueudedjim K., Bianpambé H. W., G. E. Ntamack, S. Charif D'Ouazzane and Annouar M., Anisotropic behaviour of natural wood palmyra (Borassus aethiopum Mart.) of Chad. International Journal of Mechanical Engineering and Technology (IJMET), Vol. 6, Issue 9, Sept. 2015, pp. 102-111, http://www.iaeme.com/IJMET/issues.asp?JTypeIJMET\&VTy $\mathrm{pe}=6 \&$ IType $=9$, ISSN Print: 0976-6340, ISSN Online: 09766359 . 